\title{
ECONOMIC AND FINANCIAL EFFECTS OF SPECIFIC TAXES AT THE STATE LEVEL IN THE UNITED STATES
}

\section{N. B. Ermasova, C. Barwegen, D. Vick}

Natalia B. Ermasova, https://orcid.org/0000-0001-9813-483X, Governors State University, 1, University Parkway, University Park,60430, USA, nermasova@govst.edu

Charles Barwegen Jr., https://orcid.org/0000-0001-6009-7746, Governors State University, 1, University Parkway, University Park, 60430, USA, cbarwegen@outlook.com

Dwight Vick, https://orcid.org/000-0002-8934-359X, Managed Care Center for Addictive and Other Disorder, Lubbock, Texas, 79416, USA, dwight12vick@msn.com

Introduction. This study describes states' government experiences implementing new tax laws on goods with harmful properties. It provides a comparative analysis of new tax revenues in Colorado, Washington, Oregon, and Alaska. Theoretical analysis. This paper explores the unintended consequences of new tax laws on state level in the United States. This article analyzes potential economic, health and fiscal effects based on Pigovian taxes approach. Pigovian economics discourages negative social activity by increasing tax burden associated with consumption without eliminating it or forcing it underground. Accordingly, taxes imposed on harmful commodities are intended to encourage people and businesses to consider the extra social cost when they decide to undertake the taxed item. Empirical analysis. This paper analyses the new tax laws in Colorado, Washington, Oregon, and Alaska and tax revenues on harmful commodities. It provides comparative analysis of different types of taxes and fees in 19 states. Results. The research shows the negative outcomes of its new tax initiatives -increased addiction rates, a increase level of expenditures on public health, etc. - with potentially positive ones - reduced prison populations, increased tax base, etc. The new tax policy shift will potentially cause a shift in expenditures from law enforcement to public health needs. New taxes laws on will increase state revenues on harmful commodities but also increase expenditures on public health and addiction-related costs.

Key words: state government, tax reform, financial policy, social economy.

DOI: https://doi.org/10.18500/1994-2540-2018-18-4-442-449

\section{Introduction}

According to the National Conference of State Legislatures, "the Great Recession was the defining economic event of the last 80 years. Closing huge budget gaps and managing massive revenue shortfalls topped legislative agendas for several years" [1]. Various approaches have been considered and implemented by state governments to increase revenues by taxing items such as video gambling, sexbased industries, and intoxicants. To reduce budget

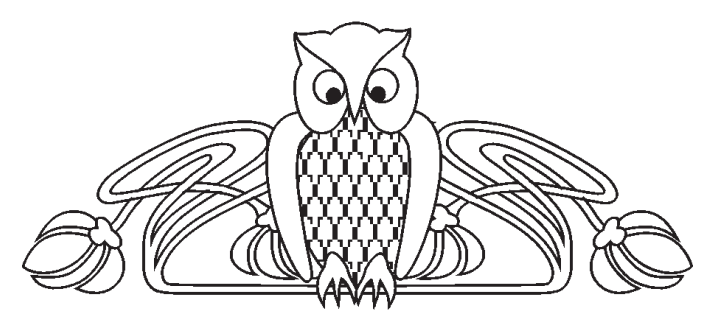

deficits, federal and state governments increased the "sin tax" on items such as tobacco, alcohol, furs, luxury automobiles, guns and ammunition. These additional taxes brought an additional $\$ 6$ billion by 2010 [2]. As the recession deepened, state governments raised taxes on soda. Some states, including Illinois, imposed new taxes on specific items like snack foods, pornography, and lap dances at stripper clubs. There are many different approaches like the "sweet tax", "marijuana tax", "soda tax", "pole tax", "video tax", and other sin- or luxury-based items. Decriminalizing marijuana for medical use and creating state-licensed dispensaries are consistent with the state's need to increase a variety of taxing sources. Ekins and Henchman (2016) write that "a mature marijuana industry could generate up to $\$ 28$ billion in tax revenues for federal, state, and local governments, including $\$ 7$ billion in federal revenue: $\$ 5.5$ billion from business taxes and $\$ 1.5$ billion from income and payroll taxes" [3, p. 3].

This article addresses the implications of statelevel legalization of marijuana for tax revenues, potential economic, health and fiscal effects. The first part of this paper provides policy debate about legalization of marijuana. Second part analyzes Pigovian taxes. Next sections cover the potential health and fiscal impact of legalization of recreational and medical marijuana. The article provides history of legalization of marijuana for medical and recreational use in different states and highlights how state legalization would affect the social sphere, the economics of the marijuana drug trade in surrounding states and how legalization would affect the economics of drug use. Finally, this research provides a comparative analysis of marijuana tax revenues in different states and examines differences in state's marijuana tax revenues. The last part provides conclusions and suggestions for future studies.

\section{Theoretical analysis}

Federal, state, and local governments placed no legal controls on illicit substances from 1800 to the late 1870s. Local and state governments passed drug control measures consistent with their moral beliefs. Communities that are more conservative were more likely to pass prohibitive drug control laws with strong law enforcement components, particularly if 
poor citizens, women, and/or racial minorities were the primary consumers. More liberal communities, usually urban, supported more liberal control efforts. Eventually, the federal government passed similar laws despite one-third of all duties paid to their governments derived from alcohol- and tobacco-based products [4]. According to Himmelstein (1983), outlawed by the 1937 Marijuana Tax Act, the drug was listed as a legitimate medicine in the United States Pharmacopedia from 1850 to 1942 [5, p. 22]. The federal 1970 Controlled Substances Act lists marijuana as a Schedule I drug, a category stating that all drugs within it have no medical use and are highly addictive. Its classification as a Schedule I drug groups marijuana with drugs that have a high potential for abuse, no legitimate medical use, and having no accepted safety levels if given for medical treatment. Federal agencies provided enforcement and financial support to state and local governments facing a drug epidemic. Once the substance was preferred by wealthier citizens, both genders, and/or Caucasians, laws were rewritten that decreased the legal severity of possessing and using the intoxicant. The substance was legalized de facto and governments imposed heavy taxes on the product [6].

Marijuana decriminalization efforts began in the 1970s for two primary reasons. First, marijuana was widely used by all segments of the population, particularly among young adults. Second, both recession and inflation gripped the American economy during the 1970s. Politicians at all levels sought to decriminalize marijuana as an effort to control addiction rates, expand its tax base, reduce law enforcement expenditures and expand rehabilitation efforts. This ended in 1981 with the election of conservative Ronald Reagan to the presidency and the beginning of a new and currently active conservative movement.

Despite federal laws banning any marijuana consumption and its corresponding enforcement laws, states responded to public demands for the passage and implementation of medical marijuana laws. Johns shows that "the decision regarding adoption was a result of a combination of policy determinants (both cultural and economic) and policy diffusion (from prior policies on medical marijuana)" [7, p. 193]. Colorado, Washington, Oregon, Alaska, California, Nevada, Maine, and Massachusetts and District of Columbia passed de facto legalization policies for recreational use of marijuana.

President Trump has signed into law H.R. 244, the Consolidated Appropriations Act, 2017, which authorizes appropriations that fund the operation of the Federal Government through September 30, 2017. A contradiction exists between the federal prohibition of marijuana and the legalization of it in several states. Marijuana remains on Schedule I of the Controlled Substances Act, the category reserved for dangerous drugs with a high potential for abuse and no accepted medical use. The Office of the Deputy Attorney General issued guidance to U.S. attorneys (federal prosecutors) to focus marijuana enforcement efforts on criminal trafficking, use by minors, and activities on federal land in 2014. Additionally, the Office of the Deputy Attorney General issued "Guidance Regarding Marijuana Related Financial Crimes" that added financial crimes such as money laundering in 2014. Congress has prohibited the Justice Department from interfering with state laws implementing medical marijuana since Fiscal Year 2015. Hechman and Scarboro suggest that "the continued status of marijuana as illegal under federal law has resulted in state-authorized marijuana retailers encountering difficulty accessing banking services, mailing customers, and securing and enforcing lease agreements" [8, p. 14]. The US Justice Department will not prosecute anyone obtaining medical marijuana; however, Nebraska and Oklahoma are suing Colorado in federal court because the state violates the Controlled Substance Act and persons are purchasing marijuana in Colorado and transporting it into their respective states where it remains an illegal substance.

Medical marijuana opponents argue that the federal Controlled Substance Act makes any form of marijuana use illegal. All states' medical marijuana laws are unconstitutional because federal laws and international treaties supersede state policies. Legalists refer to the country's history of high addiction rates in the $19^{\text {th }}$ and $20^{\text {th }}$ centuries that led to its strict federal control laws. The passages of relaxed drug-related laws that potentially decrease citizen confidence in a government to inform, regulate, or research any other product that may harm society. The anti-marijuana decriminalization supporters recognize the drug's addictive qualities.

Joffe and Yancy centered on how Colorado has handled problems with its medical marijuana legislation would serve as an example for other states looking to implement such laws [9]. The authors looked at the potential impact of legalizing marijuana would have on youth. Miron shows harm caused by drug prohibition- increased prison populations, underground and unregulated markets, etc. [10]. Miron does not deny the effects these substances have on its users, but that the outcomes of use can more accurately be attributed to the current legal treatment of drugs.

This policy debate has waged between these groups over a century. Highly salient, the pendulum of public support swings from criminalization in the 1930s toward de facto legalization of medical 
marijuana and recreational use. Medical marijuana supporters utilized similar de facto legalization arguments that were used in 37 other states that have legalized the drug for medical use. This change in public attitude toward the medical and recreational use of marijuana increased with information about its financial savings. Nationally, the sales of legal marijuana generated an estimated $\$ 1.7$ billion in state tax revenue in 2011 thereby supporting the proponents' claims about medical marijuana's benefits [11].

Burman and Slemrod suggest that Pigovian taxes, named after the British economist A.C. Pigou, were designed to reduce negative externalities caused by unhealthy or illicit activity [12]. The logic applies to sin taxes. Sin taxes are designed to reduce specific behaviors thought to be harmful to society. State and federal taxes on tobacco products, alcoholic beverages, gambling, and guns and ammunition are few of the sin-based commodities. Medical marijuana joins the sin tax commodity list. Idyllically, the tax rate should equal the social damage caused by the externality. Nye questions claims that the identification and measurement of a Pigovian externality is a sufficient condition for determining the optimal level of the tax [13]. For example, a number of prominent economists from across the political spectrum content Pigovian taxes are applied to gasoline consumption as a potential means of dealing with unpriced externalities caused by polluting, oil-reliant engines.

Accordingly, taxes imposed on harmful commodities are intended to encourage people and businesses to consider the extra social cost when they decide to undertake the taxed item. Mann, Zalcman, Asbridge, Suurvali, and Giesbrecht highlighted the negative externalities of such as the components of alcohol use stating, "it can be criminal and lead to death or permanent injury of not only for the indulger but innocent citizens as well. The impact of impaired driving by drunk drivers remains a leading cause of preventable deaths in North America and elsewhere" [14, p. 325]. It is highly unlikely that consumers would agree or even conceive of having the government raise taxes on their unhealthy consumptions. The entire excise taxes levied on sinful commodities there is a harmful environmental effect. For the most part, those who opposed sin taxes are those who indulge in them or the limited population that are not directly affected by the consumptions of sinful indulgences.

Given the historical evidence and economic problems states are facing, it is understandable why legalizing medical marijuana is commonplace. Researchers from The ArcView Group, a cannabis industry investment and research firm based in Oakland, California, found that the U.S. market for legal cannabis grew 74 percent in 2014 to $\$ 2.7$ billion, up from $\$ 1.5$ billion in 2013 . According to NEWUS Cannabis Retail Sales Projections U.S. market for legal cannabis will be around \$7.4-8.2 billion in 2018 .

The econometric literature shows that use goes up when prices go down for marijuana [15]. Initiation and use of marijuana by youth is particularly price sensitive. Caulkins and Bond analyze how diverted legal production would substantially undercut current prices. They found that "if one state legalized, then (illegal) interstate "exports" could depress marijuana prices throughout the United States, even if taxes are collected before diversion and export. The authors proxy smuggling costs by the current gradient in prices observed for Mexican or commercial-grade marijuana; based on seven different data sets, it appears to be roughly US\$325 to US\$475 per pound per 1,000 miles as one moves north from the Mexican border" [16, p. 28]. This information could be used to predict what will happen if marijuana is legalized in other states. If such a study were ever conducted in Illinois, it would serve as portent in the shaping of public policy if public opinion of the state should sway in favor of legalization.

\section{Empirical analysis}

Historical evidence supports that marijuana has medical benefits and costs. It is believed to manage pain, treat neurological disorders, increase appetite and improve sleep quality. Various ancient civilizations record using marijuana to treat a variety of ailments. It was a frequently used as a major ingredient in over-the-counter medications sold in mail-order catalogs and peddlers throughout the $19^{\text {th }}$ and early $20^{\text {th }}$ Century America. Furthermore, marijuana was considered a legitimate drug by physicians until it was removed from the United States Pharmacopedia in 1942 (the earlier version of today's Physician's Desk Reference). Yet, the drug was a contributing factor to much higher addiction rates prior to the passage of the 1914 Harrison Act and the 1937 Marijuana Tax Act prohibited any further medical research into the drug. Today, it is popularly believed that marijuana is a safer alternative than cocaine, heroin, alcohol, and tobacco despite its status within the Controlled Substance Act. The drug could be used in the treatment of HIV/AIDS, cancer, neurological disorders, glaucoma, anxiety, and mental disorders.

Policy advocates popularly claim tobacco is more harmful than marijuana yet tobacco is legal. Because of the long-term legal restrictions on marijuana research and use, there have been fewer comparative studies on marijuana than tobacco on the respiratory system. 
However, marijuana users are more likely to be poly-drug consumers thereby making the drug's long-term effects harder to isolate. Kempker, Honig and Martin prove the respiratory negligible effects of long term marijuana use. They found that greater than 20 joint-years of cumulative marijuana exposure was associated with a twofold increased odds of a $\mathrm{FEV}_{1} /$ $\mathrm{FVC}$ less than $70 \%$, this was the result of an increase in $\mathrm{FVC}$, rather than a disproportional decrease in $\mathrm{FEV}_{1}$ as is typically associated with obstructive lung diseases [17, p. 135]. Smoking marijuana can lead to similar lung-related illnesses that tobacco smokers risk: 1) bronchial irritation and bronchitis; 2) inflammation of the lung tissue; 3 ) reduced lung capacity; and 4) development of pre-cancerous cells. Marijuana produces four-times the amount of tar that is found in one tobacco cigarette, a leading contributor to lung and/or oral cancers, chronic obstructive pulmonary disease (COPD), and other respiratory diseases. Marijuana depresses the immune system. It reduces the body's ability to fight off bacteria, fungi, or tumor cells. While the drug may prevent weight loss, HIV/ AIDS patients are at higher risks of infection that can outweigh the benefits of marijuana consumption. Similar wasting situations exist for persons battling cancer who are undergoing chemotherapy or radiation treatment. Comparable situations exist with persons suffering from mental health illnesses and consume marijuana for symptom control.

While the drug's proponents claim marijuana reduces anxiety and negative impact of various mental illnesses, long-term marijuana consumption is listed as a separate mental illness in the American Psychiatric Association's Diagnostic and Statistical Manual for Mental Illness (DSM-V). Three of seven criteria must be met for a mental health professional to diagnose a client with any addiction. Marijuana's psychological short-term effects are impaired perception, slowed cognition, and short-term memory loss. The two major components are tolerance and withdrawal. The marijuana-addicted person has an increased tolerance to the substance while achieving a lesser desired effect brought on by ingestion. The person takes unusual measures to avoid withdrawal symptoms yet persistently desires to deduce or stop consumption. Meanwhile, s/he misses important social, occupational, or recreational activities because of one's drug use despite recurring physical or psychological problems caused by the substance.

Persons addicted or abusing marijuana to treat existing mental health conditions, often times find the symptoms of pre-existing conditions are exacerbated when THC is consumed. Pedersen et al. examined the association between mental health symptoms and marijuana expectancies on marijuana use and consequences for youth involved in the juve- nile court system. They found that "stronger positive expectancies and weaker negative expectancies were both associated with increased marijuana use. Youth who reported more symptoms of both anxiety and depression, and stronger positive expectancies for marijuana also reported more consequences" [18, p. 151]. This is particularly true for persons suffering from manic-depression or bipolar disorder, borderline personality disorder, clinical depression, or schizophrenia. Even when these mental health issues are not present, the consumption of THC can cause panic attacks, flashbacks, delusions and hallucinations, paranoia, extreme lethargy, and uncontrolled aggression. A person could be prescribed the drug and experience negative side effects that are listed in DSM-V. As a result, there are health benefits for legalizing medical marijuana but there are also financial and social costs. Miron suggests that sin taxation, subsidized treatment, medicalization, needle exchanges, and the use of public education campaigns are some of the other methods that can be used to reduce the negative effects of drug use.

\section{Results}

In the 2012 elections, legislation was passed effectively legalizing the recreational use of marijuana in the states of Colorado and Washington. In Washington the State Liquor Control Board are responsible for the implementation of Initiative 502, which regulates marijuana production, distribution, and possessions for those persons over 21 years of age. In this instance, licenses and fees will be applicable on those who wish to become a producer, processor, and retailer of marijuana (Washington State Implementation Fact Sheet, 2012). The fee for each license is $\$ 250$ for the application fee and $\$ 1000$ annual renewal fee [19]. Keep in mind these are three separate licenses for being a producer, processor, and retailer. Therefore, to obtain all three licenses, which the law allows, the annual fee would apply to all three licenses. Initiative 502 also allows the WSLCB to charge fees for anything done to implement or enforce the Act. This could include fees charged for the sampling, testing, and labeling that would be the cost of doing business as a licensee. The initiative has also created a few taxes in conjunction along with the law. This includes an excise tax equal to $25 \%$ of the selling price on each sale between licensed producer and processor, 25\% of the selling price between processor and retailer, and another $25 \%$ of the selling price on all retail sales of usable marijuana or marijuana infused products. Washington's Office of Financial Management has placed the price estimate of $\$ 12$ per gram based on the average medical marijuana dispensary price that ranges from $\$ 10$ to $\$ 15$ per gram. The fees, licenses, 
and taxes that are incurred to pay in order become a part of the production, processing, and sale of marijuana, it can be inferred that marijuana sales have the potential to generate a substantial amount of revenue for the state of Washington. The potential impact on Washington's fiscal estimates for the next five years seems positive. Washington's Office of Finances and Management have estimated that in a fully functioning marijuana market, state revenues could be as high as $\$ 1,943,936,000$. According to the state Liquor Control Board, Washington state has issued 86 retail marijuana licenses, and 70 stores have opened. The revenue from total sales of recreational marijuana - including between producers, processers and product sold by retailers - totaled more than $\$ 40$ million, with the state receiving more than $\$ 10$ million in excise taxes in 2015. The revenue forecast by the Economic and Revenue Forecast Council shows that the marijuana market is expected to bring in $\$ 43$ million from a variety of marijuana-related taxes including excise, sales, and business taxes - through the middle of 2016 and around $\$ 694$ million in state revenue through the middle of 2019. About $\$ 237$ million is expected to be collected till mid-2017, and \$415 million more is expected for the 2017-2019 budget biennium [20].

This is a fair estimation as Colorado's fees and taxes seem higher than that of Washington (Table). Total marijuana revenue includes the $2.9 \%$ medical and recreational marijuana sales tax, 10\% retail marijuana special sales tax, 15\% marijuana excise tax, and retail/medical marijuana application and license fee. In September 2015 were collected $\$ 13,181,758$ marijuana tax, licenses, and fees, in August 2015 - \$11,608,684 marijuana tax, licenses, and fees in comparison to \$7,741,167 in September 2014 and \$6,027,901 in August 2014 (increase by $70.3 \%$ in September and $92.6 \%$ in August). Table 1 shows how other states implemented medical marijuana laws in 18 states.

Colorado spent first $\$ 40$ million of marijuana tax revenue for school construction and \$12 million for youth and substance-abuse programs in 2014.

There were nine state ballot measures regarding the legalization of marijuana that voted on November, 2016. Arizona, California, Maine, Massachusetts and Nevada proposed to legalize recreational marijuana. Arkansas, Florida, Montana and North Dakota proposed medical marijuana legislation.

\section{Conclusion}

The potential impacts of the legalization of marijuana appear to have mixed results aspects. Over 50 percent of Americans support marijuana legalization. Washington's Initiative 502 and Colorado's Amendment 64 will have to be evaluated by policy makers. Yet, their legalization approaches are different. Washington state's program establishes separate licenses for producers, processors, and retailers while Colorado's program creates a virtually integrated supply chain. Both approaches are very different but sound policy approaches. Both states must balance the need to decrease demand for illegally-obtained marijuana and removing the criminal element associated with possession. One major concern among all states that decriminalized medical and/or recreational marijuana use is its increased availability among youth.

For decades, the Netherlands has implemented de facto/harm reduction measures to control marijuana. The Dutch government's implementation of its harm reduction policies created a de jure marijuana legalization program while maintaining its criminalization laws. Open marijuana consumption in "coffee shops" began and expanded. The Netherlands reports one of the lowest marijuana abuse rates among European countries. Its de jure marijuana laws allows law enforcement officers to focus upon users and dealers of harder drugs like heroin and cocaine. Its arrest rates for marijuana users are 19 persons per 100,000, ten times less than in the United States. However, the policy created a "drug tourist" industry. Foreign visitors, primarily from bordering European countries travelled to the Netherlands to consume marijuana. These tourists were arrested upon return to their home countries where use and possession remain illegal. Similar situations exist within Nebraska and Oklahoma, two states that border Colorado.

Pigovian economics provides an ideal economic framework to base states' recreational and medical marijuana tax policies. The system shows the negative outcomes of its medical marijuana initiatives - increased addiction rates, a shift toward public health, etc. - with potentially positive ones - reduced prison populations, increased tax base, etc. The Dutch experiment of de jure criminalization of marijuana shows, in part, that the shift reduces the legal ramifications of both medical and recreational use of marijuana. Both Colorado and Washington's examples provide two different approaches that other states can follow to decriminalize both forms of use. The policy shift will increase revenues but potentially cause a shift in expenditures from law enforcement to public health needs. Medical marijuana taxes will increase state revenues but also risk increasing public health and addiction-related costs. Furthermore, the shift toward decriminalisation of medical and recreational marijuana does not eliminate criminal justice-related costs.

However, the economic, political, and social implications show that marijuana law could lead 


\section{Medical Marijuana Dispensary Laws by State}

\begin{tabular}{|c|c|c|}
\hline State & Application and/or Registration Fee & Taxes \\
\hline Arizona & $\begin{array}{l}\$ 5,000 \text { application fee } \\
\$ 1000 \text { renewal }\end{array}$ & $5.6 \%$ sales tax \\
\hline California & Varies, all licensing is local & $7.5 \%$ state sales tax \\
\hline Colorado & $\begin{array}{l}\text { Applications: } \$ 7,000 \text { to } \$ 15,000 \text { for medical marijuana centers, } \\
\$ 1,000 \text { for infused product manufacturers; Registrations: } \$ 5,200 \text { to } \\
\$ 13,200 \text { for centers, } \$ 2,200 \text { for infused product manufacturers. } \\
\text { Renewals: } \$ 5,800 \text { to } \$ 13,800 \text { for centers, } \$ 2,500 \text { for infused product } \\
\text { manufacturers }\end{array}$ & $\begin{array}{l}2.9 \% \text { state sales tax, } \\
\text { also local taxes }\end{array}$ \\
\hline Connecticut & $\begin{array}{l}\text { Applications: } \$ 1,000 \text { for dispensaries; } \$ 25,000 \text { for producers. } \\
\text { Permit and annual renewal fees: } \$ 5,000 \text { for dispensaries; } \\
\$ 75,000 \text { for producers }\end{array}$ & $\begin{array}{l}6.35 \% \text { state sales tax } \\
\text { applies }\end{array}$ \\
\hline Delaware & $\begin{array}{l}\$ 5,000 \text { compassion center application fee. } \\
\$ 40,000 \text { compassion center certification and biennial renewal fee }\end{array}$ & $\begin{array}{l}\text { Gross receipts tax if } \\
\text { above } \$ 1.2 \text { million in revenue }\end{array}$ \\
\hline Illinois & $\begin{array}{l}\$ 25,000 \text { non-refundable application fee } \\
\$ 100,000 \text { annual }\end{array}$ & $\begin{array}{l}7 \% \text { excise tax at the whole } \\
\text { sale level; } 1 \% \text { sales tax }\end{array}$ \\
\hline Maine & $\begin{array}{l}\$ 15,000 \text { application fee, } \$ 14,000 \text { refunded to applicants that aren't } \\
\text { chosen; } \$ 15,000 \text { renewal fee }\end{array}$ & $\begin{array}{l}5 \% \text { sales tax and } 7 \% \text { meals } \\
\text { and rooms tax on edibles }\end{array}$ \\
\hline Maryland & $\begin{array}{l}\text { Fees in proposed rules: } \\
\text { Application fees (in two stages): for growers } \\
\$ 6,000 \text {; for growers/dispensaries: } \$ 11,000 \text {; for dispensaries only: } \\
\$ 5,000\end{array}$ & $\begin{array}{l}\text { Likely not taxed; } \\
\text { Maryland } 6 \% \text { sales tax } \\
\text { does not apply to the sale } \\
\text { of medicine }\end{array}$ \\
\hline Massachusetts & $\begin{array}{l}\$ 1,500 \text { stage } 1 \text { application fee; } \$ 30,000 \text { stage } 2 \text { application fee; } \\
\$ 50,000 / \text { year license registration fee }\end{array}$ & N/A \\
\hline Minnesota & $\begin{array}{l}\$ 20,000 \text { manufacturer application fee; the annual } \\
\text { fee is not yet set, but is expected to be between } \$ 75,000 \text { and } \\
\$ 100,000\end{array}$ & N/A \\
\hline Nevada & $\begin{array}{l}\$ 5,000 \text { medical marijuana establishment application fee; } \\
\$ 3,000 \text { cultivation facility certification fee; } \\
\$ 5,000 \text { independent testing laboratory certification fee; } \\
\$ 30,000 \text { medical marijuana dispensary }\end{array}$ & $\begin{array}{l}6.85 \% \text { to } 8.1 \% \\
\text { sales tax, in addition to a } 2 \% \\
\text { excise tax }\end{array}$ \\
\hline N. Hampshire & $\$ 80,000-40,000$ & N/A \\
\hline New Jersey & $\begin{array}{l}\$ 20,000 \text { dispensary fee each year, } \$ 2,000 \text { for unsuccessful } \\
\text { applicants }\end{array}$ & $7 \%$ sales tax \\
\hline New Mexico & $\begin{array}{l}\$ 1,000 \text { application fee for producers, annual producer fee } \\
\text { from } \$ 5,000-\$ 30,000\end{array}$ & $\begin{array}{l}\text { Gross receipts tax } \\
(5.125 \% \text { to } 8.8675 \%)\end{array}$ \\
\hline New York & $\$ 200,000$ & $\begin{array}{l}7 \% \text { excise, anticipated } \\
\text { percentage of } 7 \% \text { sales tax }\end{array}$ \\
\hline Oregon & $\$ 4,000$ & $\mathrm{~N} / \mathrm{A}$ \\
\hline Rhode Island & $\$ 250$ application fee, $\$ 5,000$ biennial registration fee & $\begin{array}{l}\text { Compassion center } \\
\text { surcharge of } 4 \% ; 7 \% \text { state } \\
\text { sales tax }\end{array}$ \\
\hline Vermont & $\$ 2,500$ application fee, $\$ 20,000$ or $\$ 30,000$ fee & N/A \\
\hline $\begin{array}{l}\text { Washington } \\
\text { D.C. }\end{array}$ & $\begin{array}{l}\$ 5,000 \text { application fee for dispensaries } \\
\text { and cultivators, } \$ 3,000 / \text { year renewal fee; } \$ 10,000 / \text { year fee } \\
\text { for dispensaries; } \$ 5,000 / \text { year fee for cultivators }\end{array}$ & $\begin{array}{l}6 \% \text { sales tax, revenue } \\
\text { unknown }\end{array}$ \\
\hline
\end{tabular}

Source: Marijuana Policy Project, 2017 (https://www.mpp.org/). 
to trouble with neighboring states that have not decriminalized marijuana. In Colorado, around 40 percent in Denver and 80 percent in mountain areas of recreational marijuana buyers were from neighboring states. The significant attention must be given to health, agricultural, zoning, local enforcement, and criminal penalty issues of legalization of marijuana. Future papers should focus on specific economic issues relating to marijuana legalization and explore in more detail the environmental, medical, criminal, spiritual, productivity and other social costs of legalization.

\section{References}

1. National Conference of State Legislatures. Assessing 2014 's top state fiscal issues. 2014. Available at: http:// www.ncsl.org (accessed 7 February 2018).

2. Lorenzi P. Taxing antisocial behavior for the common good. Society, 2010, vol. 47, no. 4, pp. 328-332.

3. Ekins G., Henchman, J. Marijuana Legalization and Taxes: Federal Revenue Impact. 2016. Available at: https://taxfoundation.org/marijuana-tax-legalizationfederal-revenue/ (accessed 9 April 2017).

4. Snowdon C. The wages of sin taxes. 2012. Available at: http://www.adamsmith.org/sites/default/files/research/ files/The $\% 20$ Wages $\% 20$ of $\% 20 \operatorname{Sin} \% 20$ Taxes $\% 20$ CJ $\% 20$ Snowdon\%20ASI_0.pdf (accessed 9 April 2017).

5. Himmelstein J. L. The Strange Career of Marihuana: Politics and Ideology of Drug Control in America. Praeger, Greenwood Press, USA, 1983. 179 p.

6. Vick D., Rhoades E. Drugs and alcohol in the 21st Century. Sudbury, Massachusetts, Jones and Bartlett Publishers, USA, 2011. 400 p.

7. Johns T. Managing a Policy Experiment: Adopting and Implementing Recreational Marijuana Policies in Colorado. State and Local Government Review, 2015, vol. 47, no 3, pp. 193-204.

8. Henchman J., Scarboro M. Marijuana Legalization and Taxes: Lessons for Other States from Colorado and Washington. Tax Foundation. 2016. Available at: http:// taxfoundation.org/article/marijuana-legalization-andtaxes-lessons-other-states-colorado-and-washington (accessed 15 April 2017).
9. Joffee A., Yancy S. Legalization of Marijuana: Potential Impact on Youth. American Academy of Pediatrics, 2004, vol. 113, no. 6, pp. 1-14.

10. Miron J. The Economics of Drug Prohibition and Drug Legalization. Social Research, 2001, vol. 68, no 3, pp. 835-855.

11. Ludlum M., Ford D. Colorado's 2010. Update to the Medical Marijuana Law: Three Problems, Three Solutions. Mustang Journal of Law and Legal Studies, 2011, vol. 2, pp. 73-77.

12. Burman L. E., Slemrod J. Taxes in America: What everyone needs to know. New York, NY, Oxford Press University, 2013. 304 p.

13. Nye J. The Pigou Problem. Regulation, 2008, vol. 3, pp. 32-37.

14. Mann R. E., Zalcman R. F., Asbridge M., Suurval, H., Giesbrecht N. Drinking-driving fatalities and consumption of beer, wine and spirits. Drug and Alcohol Review, 2006, vol. 25, no 7, pp. 321-325.

15. Williams R., Christ, K. Taxing sin. Mercatus on Policy, 2009, vol. 55, no. 4, pp. 14-19.

16. Caulkins J. P., Bond B. M. Marijuana Price Gradients: Implications for Exports and Export-Generated Tax Revenue for California After Legalization. Journal of Drug Issues, 2012, vol. 42, no. 1, pp. 28-45.

17. Kempker J., Honig E., Martin G. The Effects of Marijuana Exposure on Expiratory Airflow. A Study of Adults who Participated in the U.S. National Health and Nutrition Examination Study. Annals of the American Thoracic Society, 2015, vol. 12, no. 2, pp. 135-141.

18. Pedersen E., Miles N., Osilla K., Ewing B., Hunter S., D'Amico E. The Effects of Mental Health Symptoms and Marijuana Expectancies on Marijuana Use and Consequences Among At-Risk Adolescents. Journal of Drug Issues, 2015, vol. 45, no. 2, pp. 151-165.

19. Washington State Liquor Control Board. Fiscal Impact through Fiscal Year 2017. 2018. Available at: http:// www.liq.wa.gov/publications/Marijuana/I-502/502_ fiscal_impact.pdf (accessed 19 April 2018).

20. La Corte, R. Legal Pot in Washington Bringing in Even More Tax Revenue Than Predicted. Huffington Post Business, 2015. October, 20. Available at: http://www. huffingtonpost.com/2014/11/20/legal-pot-washingtonmarket-tax-revenue_n_6191848.html (accessed 15 April 2018).

\section{Cite this article as:}

Ermasova N. B., Barwegen C., Vick D. Economic and Financial Effects of Specific Taxes at the State Level in the United States. Izv. Saratov Univ. (N. S.), Ser. Economics. Management. Law, 2018, vol. 18, iss. 4, pp. $442-449$ (in Russian). DOI: https://doi.org/10.18500/1994-2540-2018-18-4-442-449

\section{Экономические и финансовые эффекты специфических региональных налогов в Соединенных Штатах}

\section{Н. Б. Ермасова, Ч. Барвеген, Д. Вик}

Ермасова Наталья Борисовна, доктор экономических наук, профессор, Губернаторский государственный университет штата Иллинойс, Университетский парк, США, nermasova@govst.edu
Барвеген Чарльз, MPA (Master of Public Administration/магистр государственного управления), специалист по обеспечению качества, Губернаторский государственный университет штата Иллинойс, Университетский парк, США, cbarwegen@outlook.com

Вик Двайт, доктор экономических наук, исполнительный директор, Лечебный центр от наркотической и другой зависимости, Лаббок, США, dwight12vick@msn.com 
Введение. В статье описывается опыт США в реализации нового налогового законодательства в отношении товаров С вредными свойствами на уровне штатов. В статье проводится сравнительный анализ новых налоговых поступлений в Колорадо, Вашингтоне, Орегоне и Аляске. Теоретический анализ. В статье рассматриваются последствия нового налогового законодательства на государственном уровне в Соединенных Штатах. Анализируются потенциальные экономические, медицинские и финансовые результаты этих новых налоговых инициатив. Анализ использует подход социальной экономики и уменьшения негативной социальной активности при увеличении налоговой нагрузки на товары с вредными свойствами. Эмпирический анализ. В статье анализируются новые налоговые законы в штатах
Колорадо, Вашингтон, Орегон и Аляска и налоговые поступления от налогоовобложения товаров с вредными свойствами. Проводится сравнительный анализ различных видов налогов и сборов в 19 штатах. Результаты. Исследование показало, что вследствие новых налоговых инициатив происходит повышение уровня зависимости от вредных веществ, увеличение уровня расходов на здравоохранение, при этом есть положительные результаты сокращение численности заключенных и увеличение налоговой базы. Новая налоговая политика вызывает сдвиг в расходах от правоохранительных органов к расходам на общественное здравоохранение.

Ключевые слова: региональные налоги, налоговые реформа, финансовая политика, социальная экономика.

\section{Образец для цитирования:}

Ermasova N. B., Barwegen C., Vick D. Economic and Financial Effects of Specific Taxes at the State Level in the United States [Ермасова Н. Б., Барвеген Ч., Вик Д. Экономические и финансовые эффекты специфических региональных налогов в Соединенных Штатах] // Изв. Сарат. ун-та. Нов. сер. Сер. Экономика. Управление. Право. 2018. Т. 18, вып. 4. C. 442-449. DOI: https://doi.org/10.18500/1994-2540-2018-18-4-442-449 